\title{
TOMATO PROCESSING FIRMS' MANAGEMENT: A COMPARATIVE APPLICATION OF ECONOMIC AND FINANCIAL ANALYSES
}

\author{
Mattia Iotti and Giuseppe Bonazzi \\ Department of Civil Engineering, Environment, \\ Territory and Architecture-DICATeA, University of Parma, Parma, Italy
}

Received 2014-02-12; Revised 2014-03-16; Accepted 2014-04-28

\begin{abstract}
In Italy, the territory that includes the Emilia-Romagna region, the southern areas of Lombardia and some of Piemonte's territory is a center of national importance for tomato production and transformation. The processing firms operating in this area are characterized by significant investments in fixed assets and working capital. The article analyzes the annual account data of a sample of firms, showing that economic margins traditionally applied to assess the sustainability of the business cycle differ significantly from financial margins; also, the Interest Coverage Ratios (ICRs) differ if calculated by applying an economic or a financial approach. Moreover, the annual account data highlight difficult credit access, expressed by applying a multiple regression model to analyze Free Cash Flow to Equity (FCFE) generation. The article suggests a useful metric to measure more correctly the sustainability of a firm's management that could be applied to others in the agri-food sector, particularly if characterized by a capital-intensive processing cycle.
\end{abstract}

Keywords: Tomato Processing Industry, Economic and Financial Analysis, Interest Coverage Ratios

\section{INTRODUCTION}

Tomato farming, with its processing industry, characterizes the economies of territories in different areas of the world. Italy along with the western areas of the United States of America, China and some Mediterranean countries, primarily Spain and Turkey is an important area for tomato production and transformation. In Italy, there are two main areas of tomato production that, at the same time, have places for tomato processing. The first area is the Campania region, with 96 processing firms, while the second area consists of the regions of Emilia-Romagna, Lombardia and Piemonte, where 25 transformation firms operate. In recent years, the tomato processing firms of EmiliaRomagna, Lombardia and Piemonte were characterized by various situations of economic crisis, which have also caused bankruptcy and liquidation as well as MandA operations and restructuring plans to avoid bankruptcy. The agri-food firms are, in fact, often capital-intensive, requiring a high level of capital to sustain the management cycle (Bonazzi et al., 2012). There are various reasons for these trends, including the rising costs of raw materials and, even at the macroeconomic level, the reduction of bank credit. Given the difficulties of the sector, the aim of this article is to analyze the management data of the tomato processing firms of Emilia-Romagna, Lombardia and Piemonte, particularly with respect to capital structure of the firms, sustainability of the management cycle and credit access. To achieve this goal, we apply the methods of analysis of a firm's data to a sample of companies, proposing and submitting to tests of statistical validity ratios and aiming at the analysis of financial debt service coverage. On this topic, there is a comparison in the article between traditional and nontraditional 
sustainability ratios, which can be applied by firms and banks in assessments of the sustainability of debt services. The analysis also applies the comparison between profit margins and financial margins in order to highlight whether there are statistically significant differences between the sample firms as characterized by the high absorption of liquidity in the financial cycle of investments and working capital. Data analysis of the sector, particularly in the current situation of crisis, aims to provide useful information for a firm's management to evaluate the sustainability of the firm's financial cycle. Firm data express the difficulty in credit access by applying a multiple regression model to analyze Free Cash Flow to Equity (FCFE) generation. The results of the article could be applied by policy makers through public actions to support private firms, including a public line of credit, in order to correctly evaluate the financial viability of firms that have received public funds, thus limiting the risk of inefficient uses of collective resources.

\section{MATERIALS AND METHODS}

For the analysis of the firms' economic and financial data, the main database component is the public annual account, which is the main accounting document in Italy for limited companies and cooperatives, according with the provision of Article 2423 of the national civil code. The annual account consists of the balance sheet, income statement and integrative note, as expressed by D. Lgs. 127/91, which applies to the fourth EU directive about company and annual accounts (EU Directive 78/660/EEC IV of July $25,1978)$. The civil code has thus disciplined a uniform information base, on the basis of accounting principles, to allow comparability of operating results between different firms. The annual account shall be used by equity holders to assess the profitability of firms, particularly to evaluate the return on equity; the analysis of annual account data is also relevant to quantify the possibility of access to bank credit. The annual account quantifies, in accordance with the accrual principle, the firm's profit that is, the change in the equity value of the company due to the management cycle (Zappa, 1950; Onida, 1987). This approach refers to the time of the creation of value without considering the inflow and outflow of cash (i.e., collection of receivables and payment of debts). This makes possible situations of mismatch between economic and financial flows (Gitman, 1994) because profit is also influenced by values that do not cause cash inflow or outflow, as evidenced by several studies about firms with high investments in fixed assets (Fazzari and Petersen, 1993; De Miguel and Pindado, 2001) and in working capital (Shin and Soenen, 1998; Howorth and Westhead, 2003; Padachi, 2006; Taylor, 2011). For a generic firm in a generic period, $t$, the balance sheet expresses investments (active section) and sources of capital (passive section). The general equation of the balance sheet, reclassifying data with a liquidity approach (i.e., according to financial criteria), is expressed as follows Equation 1:

$$
\begin{aligned}
& \mathrm{FA}_{\mathrm{t}}+\mathrm{WCi}_{\mathrm{t}}^{\mathrm{a}}+\mathrm{WCar}_{\mathrm{t}}^{\mathrm{a}}+\mathrm{WCo}_{\mathrm{t}}^{\mathrm{a}}+\mathrm{L}_{\mathrm{t}}= \\
& \mathrm{E}_{\mathrm{t}}^{\mathrm{cs}}+\mathrm{E}_{\mathrm{t}}^{\mathrm{r}}+\Pi_{\mathrm{t}}^{\mathrm{p} T}+\mathrm{WCap}_{\mathrm{t}}^{\mathrm{p}}+\mathrm{WCo}_{\mathrm{t}}^{\mathrm{p}}+\mathrm{DF}_{\mathrm{t}}^{\mathrm{M}<12}+\mathrm{DF}_{\mathrm{t}}^{\mathrm{M}>12}
\end{aligned}
$$

In (1), investments are represented by FA (fixed assets), $\mathrm{WCi}^{\mathrm{a}}$ (working capital assets, inventories), $\mathrm{WCar}^{\mathrm{a}}$ (working capital assets, trade receivables), $\mathrm{WCo}^{\mathrm{a}}$ (working capital assets, other assets) and L (liquidity); the sources of capital are represented by $\mathrm{E}^{\mathrm{cs}}$ (share capital), $\mathrm{E}^{\mathrm{r}}$ (reserves), $\Pi^{\mathrm{pT}}$ (profit after taxes), WCapp (working capital debts, accounts payable), $\mathrm{WCo}^{\mathrm{p}}$ (working capital debts, other values), $\mathrm{DF}^{\mathrm{M}<12}$ (financial debts due within 12 months) and $\mathrm{DF}^{\mathrm{M}>12}$ (financial debts due after 12 months). The first component of (1) for the generic period, $t$, represents the invested capital as Total Assets (TA) and the second component represents the total sources of capital as the sum of equity capital (ET $=$ $\left.\mathrm{E}^{\mathrm{cs}}+\mathrm{E}^{\mathrm{r}}+\Pi^{\mathrm{pT}}\right)$ and debt capital $\left(\mathrm{DT}=\mathrm{WCap}^{\mathrm{p}}+\mathrm{WCo}^{\mathrm{p}}+\right.$ $\mathrm{DF}^{\mathrm{M}<12}+\mathrm{DF}^{\mathrm{M}>12}$ ). We can then express the net position of financial credit and debt for the generic time, $t$, as Net Financial Position $\left(\mathrm{NFP}_{\mathrm{t}}\right)$ Equation 2:

$\left(\mathrm{DF}_{\mathrm{t}}^{\mathrm{M}<12}+\mathrm{DF}_{\mathrm{t}}^{\mathrm{M}>12}\right)-\mathrm{L}_{\mathrm{t}}=\mathrm{NFP}_{\mathrm{t}}$

We then consider the net investment in working capital (NWCt) that expresses the absorption of financial resources as a result of the acquisition, processing and sale cycle, which is expressed as follows Equation 3:

$$
\begin{aligned}
& \left(\mathrm{WCi}_{\mathrm{t}}^{\mathrm{a}}+\mathrm{WCar}_{\mathrm{t}}^{\mathrm{a}}+\mathrm{WCo}_{\mathrm{t}}^{\mathrm{a}}\right)-\left(\mathrm{WCap}_{\mathrm{t}}^{\mathrm{p}}+\mathrm{WCo}_{\mathrm{t}}^{\mathrm{p}}\right)= \\
& =\mathrm{WC}_{\mathrm{t}}^{\mathrm{aT}}-\mathrm{WC}_{\mathrm{t}}^{\mathrm{pT}}=\mathrm{NWC}_{\mathrm{t}}
\end{aligned}
$$

In (3), given a generic period, t, WCaT is working capital total asset and WCpT is working capital total debt; NWC quantifies the net resources generated $(\mathrm{NWCt}<0)$ or absorbed $(\mathrm{NWCt}>0)$ by the working capital management cycle (Love et al., 2007). The firms in the tomato processing tomato industry are often 
characterized by the absorption of capital to cover the cycle of processing of raw materials, so it is useful to express the reclassification of the balance sheet with the functional form (Massari, 2000) Equation 4:

$$
\mathrm{FA}_{\mathrm{t}}+\mathrm{NWC}_{\mathrm{t}}=\mathrm{NFP}_{\mathrm{t}}+\mathrm{E}_{\mathrm{t}}^{\mathrm{T}}
$$

The formulation of (4) directly expresses NWC having as sources of capital Net Financial Position (NFP) and equity capital (ET), where NFP + ET = NIC, which is net invested capital. The situation in which NWC $>0$ is called the conservative strategy of working capital management because it has been shown (Hill et al., 2010) that NWC $>0$ is inversely related to a financial crisis. The situation in which $\mathrm{NWC}_{\mathrm{t}}<0$ is defined as the aggressive strategy of working capital management (Grablowsky, 1984; Weinraub and Visscher, 1998) and is considered to be directly related to the risk of financial distress. For a generic company, given a generic period, $\mathrm{t}$, the income statement quantifies the profit, which is expressed as follows Equation 5:

$$
\begin{aligned}
& \mathrm{VP}_{\mathrm{t}}-\left(\mathrm{M}_{\mathrm{t}}+\mathrm{S}_{\mathrm{t}}+\mathrm{G}_{\mathrm{t}}+\mathrm{L}_{\mathrm{t}}+\mathrm{O}_{\mathrm{t}}\right)=\text { EBITDA }_{\mathrm{t}} \\
& \mathrm{EBITDA}_{\mathrm{t}}-\left(\mathrm{D}_{\mathrm{t}}+\mathrm{A}_{\mathrm{t}}\right)=\mathrm{EBIT}_{\mathrm{t}} \\
& \mathrm{EBIT}_{\mathrm{t}}+\mathrm{SF}_{\mathrm{t}}+\mathrm{R}_{\mathrm{t}}+\mathrm{X}_{\mathrm{t}}-\mathrm{T}_{\mathrm{t}}=\Pi_{\mathrm{t}}^{\mathrm{pT}}
\end{aligned}
$$

In (5), $\mathrm{VP}$ is the value of production, $\mathrm{M}$ is raw material costs, $S$ is service costs, $G$ is charges for the use of third-party assets such as rent and leasing, $\mathrm{L}$ is labor costs and $\mathrm{O}$ is other operating costs. Earnings Before interest, Taxes, Depreciations and Amortizations (EBITDA) is the intermediate profit margin that is applied to approximate the creation of liquidity before Depreciation (D) and Amortization (A). Earnings Before Interest and Taxes (EBIT) is the profit margin that expresses the operating income. SF is the balance of the financial factors of income, given by the algebraic sum of financial costs (OF) and revenues (PF). $\mathrm{R}$ is the balance of revaluations and devaluations in financial assets, $\mathrm{X}$ is the balance of extraordinary factors of income, $\mathrm{T}$ is income taxes and $\Pi p \mathrm{~T}$ is profit after taxes. The income statement quantifies profit as the difference between revenues and costs, applying the economic approach that differs from the financial approach because the former is based on the creation of value, while the second is based on cash flow. The economic approach is the basis for an income statement in accordance with the accrual principle as expressed in Article 2423 of the national civil code. For this reason, the income statement is not suitable for financial analysis and to quantify cash flows. In defining cash flow, which is relevant to management decisions, there was a change in researchers' approach. An early definition considers cash flow as the sum of an accounting result (profit or EBIT) plus depreciation and amortizations (Beaver, 1966); other researchers (Gombola and Ketz, 1983) began to express cash flow by taking into account the absorption or generation of cash by the working capital cycle and this approach was considered in several studies (Rayburn, 1986; Wilson, 1987; Finger, 1994; Lorek and Willinger, 1996). We can apply two methods to draft financial statements. The direct method (Dechow et al., 1998; Chittenden et al., 1998; Almeida et al., 2004) considers monetary revenues and costs as determinants of Cash Flow (CF); otherwise, the indirect method (as in Giacomino and Mielke, 1988; Carroll and Griffith, 2001) quantifies cash inflow generated by operations, deriving the analysis from an income margin (in this case, profit) Equation 6:

$$
\begin{aligned}
& \Pi_{t}^{\mathrm{pT}}+\left(\mathrm{D}_{\mathrm{t}}+\mathrm{A}_{\mathrm{t}}\right)+\mathrm{SF}_{\mathrm{t}}=\mathrm{CF}_{\mathrm{t}} \\
& \mathrm{CF}_{\mathrm{t}}-\left(\mathrm{NWC}_{\mathrm{t}}-\mathrm{NWC}_{\mathrm{t}-1}\right)=\mathrm{OCF}_{\mathrm{t}} \\
& \mathrm{OCF}_{\mathrm{t}}-\left(\mathrm{FA}_{\mathrm{t}}-\mathrm{FA}_{\mathrm{t}-1}\right)-\left(\mathrm{D}_{\mathrm{t}}+\mathrm{A}_{\mathrm{t}}\right)=\mathrm{UFCF}_{\mathrm{t}} \\
& \mathrm{UFCF}_{\mathrm{t}}-\mathrm{SF}=\mathrm{FCFE}_{\mathrm{t}}
\end{aligned}
$$

In (6), at a certain time, t, CF is cash flow, OCF is operating cash flow, UFCF is unlevered free cash flow and FCFE is free cash flow to equity. CF expresses the potential cash flow (Sartoris and Hill, 1983; Henry, 1996; Kim et al., 1998) and if we consider the change in net working capital from period $\mathrm{t}-1$ to period $\mathrm{t}$ $\left(\Delta \mathrm{NWC}_{\mathrm{t}, \mathrm{t}-1}=\mathrm{NWC}_{\mathrm{t}},-\mathrm{NWC}_{\mathrm{t}-1}\right)$, we can demonstrate that $\Delta^{+} \mathrm{NWC}_{\mathrm{t}, \mathrm{t}-1}=>\Delta^{-} \mathrm{OCF}_{\mathrm{t}}$, showing that an increase in net working capital causes an increase in absorption of liquidity, which reduces the Operating Cash Flow $\left(\mathrm{OCF}_{\mathrm{t}}\right)$ and vice versa in the case of negative change $\left(\Delta^{-} \mathrm{NWC}_{\mathrm{t}, \mathrm{t}-1}=>\Delta^{+} \mathrm{OCF}_{\mathrm{t}}\right)$. The increase of the final stock of inventory $\left(\Delta^{+} \mathrm{WCi}_{\mathrm{t}, \mathrm{t}-1}^{\mathrm{a}}\right)$, as a positive component of profit, determines a reduction of Operating Cash Flow $\left(\mathrm{OCF}_{\mathrm{t}}\right)$, of equal absolute value and the opposite sign and vice versa. The firms with positive profits, due to an increase in their inventories' value, record an equal reduction, in absolute value, of the operating cash flow (but of the opposite sign). UFCF expresses the cash flow available for the payment of debt services and thus the financial margin used for assessing debt sustainability; FCFE is net cash flow available for 
payment of profits to shareholders in the form of a distribution of dividends.

The values of the balance sheet are used in the calculation of financial ratios (Barnes, 1987) to evaluate the results of management with synthetic measures that facilitate comparison between firms. Whittington (1980) has identified two main uses of ratios: The first is to compare the results of the company with a general standard; the second is to derive predictive information on management. Recently, other researchers (Alrafadi and Md-Yusuf, 2011) have analyzed financial ratios and balanced scorecard to compare benefits and problems of using financial ratios analysis and Balanced Scorecard method. Other reserechers (Bahiraie et al., 2009) apply financial ratios to new geometric technique for empirical analysis of bankruptcy risk (Risk Box measure). The literature of bankruptcy prediction starts with the seminal work of Altman (1968), who tried to explain the state of financial distress of companies in the United States by applying financial ratios, including coverage ratios of debt service (Interest Coverage Ratios, abbreviated ICRs). The importance of ICRs has been demonstrated by several studies (Leland, 1994; 1998) showing that management control through ICRs reduces the volatility of investments. ICRs are also applied as covenants in bank financing operations (Gray et al., 2006). These ICRs are often calculated with an economic approach (i.e., having EBIT and/or EBITDA as the numerator); these covenants occur in term sheets of financing operations (Dichev and Skinner, 2002; Demerjian, 2011). The intermediate profit margins (EBITDA and EBIT) are applied to approximate cash flow in the evaluation of the sustainability of the management cycle and to quantify debt service capacity; this is an economic approach that considers profit margins (EBITDA and/or EBIT) as the ratio's numerator. The ICRs thus calculated, however, do not consider the effects of uncollected credit, unpaid debts and changes in inventories' values. ICRs calculated with an economic approach are expressed as follows Equation 7:

$$
\mathrm{ICR}_{1}=\mathrm{EBITDA}_{\mathrm{t}} / \mathrm{OF}_{\mathrm{t}} ; \mathrm{ICR}_{2}=\mathrm{EBIT}_{\mathrm{t}} / \mathrm{OF}_{\mathrm{t}}
$$

$\mathrm{ICR}_{1}$ and $\mathrm{ICR}_{2}$ express the firm's ability to pay the cost of debt in a given period, t, having EBITDA and EBIT, respectively, considered as available margins (Healy, 1985; Sloan, 1996; Goldstein et al., 2001;
Dothan, 2006). The evaluation on the basis of these ICRs may give erroneous results in cases of overestimating or underestimating the debt service coverage capacity. This approach is, however, the most frequently applied in the practice of firms and even in rating systems to evaluate access to bank credit (Basel II and Basel III Accords). Firms can assume strategic decisions based on incorrect ICRs and at the same time, banks cannot properly evaluate credit scoring. To overcome this problem, the article suggests (Iotti and Bonazzi, 2013) and also applies ICRs calculated with a financial approach, having as the numerator the financial values of OCF and UFCF. We can express this for a given period, $t$, as follows Equation 8:

$$
\mathrm{ICR}_{3}=\mathrm{OCF}_{\mathrm{t}} / \mathrm{OF}_{\mathrm{t}} ; \mathrm{ICR}_{4}=\mathrm{UFCF}_{\mathrm{t}} / \mathrm{OF}_{\mathrm{t}}
$$

$\mathrm{ICR}_{3}$ and $\mathrm{ICR}_{4}$ express the firm's capacity to pay the cost of debt, as borrowing costs (OF), using financial margins ( $\mathrm{OCF}$ and UFCF); these ratios are classified as ICRs with a financial approach and are proposed in the article in comparison between ICRs with an economic approach. About this topic, accrual and cash flow measures have been applied to evaluate firms' performance, although the results are inconclusive throughout countries and time (Nasir and Abdullah, 2004). We suggest this analysis for verifying if the firms in the sample have significant differences between the values of ICRs calculated by applying the two different approaches. This could be particularly relevant for tomato processing firms that often have a high level of invested capital and, at the same time, a high need for financial debt to cover investments in fixed assets and working capital.

\section{RESULTS}

The research starts with the analysis of parametric data (margins) considered relevant in the sample of firms. The descriptive statistics (Table 1) show that intermediate income margins (EBITDA and EBIT) have average values higher than financial margins (OCF and UFCF) and the median values of income margins are also higher than financial margins. EBITDA is positive in 79 cases and EBIT is positive in 72 cases, while OCF is positive in 55 cases and UFCF only in 45 cases. $\Pi^{\mathrm{pT}}$ (PROFIT) also has a value higher than FCFE: PROFIT is positive in 50 cases out of 85 , while FCFE is positive only in 37 
cases out of 85 . The analysis of the sample of firms shows that the intermediate income margins (EBITDA and EBIT) have average values higher than the financial margins (OCF and UFCF); at the same time, the mean values of PROFIT are higher than FCFE. The analysis thus shows that the application of intermediate margins (EBITDA) could super evaluate the financial results available for the company (UFCF and $\mathrm{OCF}$ ), expressing that the difference between income and the financial cycle is significant. In particular, the investment cycle, as expressed by UFCF, absorbs a substantial amount of liquidity of the sample firms, as it is expressed by median value of UFCF (€6,859), while EBIT has a higher positive median value $(€ 65,228)$. The analysis confirms that firms in the tomato processing sector are characterized by high investments in particular, to finance investment in fixed assets expressing that UFCF median values are not able to cover debt services. This is a typical situation for companies characterized by high capital requirements in which the evaluations of sustainability could not be done by applying income margins (EBITDA and EBIT), but it could be more correct to directly apply financial margins. The analysis of the results available for firms in the sample shows a shift between income cycle and financial cycle. In fact, the median value of PROFIT is $€ 48,122$, while the median value of FCFE is $-€ 8,532$. The analysis of profit then leads to a distorted assessment of the financial situation of the company and also of the investments made by shareholders and although they have accounting remuneration, they are unable to generate available cash flow.
With regard to the sustainability of the business cycle (Table 1), the ratios calculated with an economic approach $\left(\mathrm{ICR}_{1}\right.$ and $\left.\mathrm{ICR}_{2}\right)$ have average values higher than ratios calculated with a financial approach $\left(\mathrm{ICR}_{3}\right.$ and $\left.\mathrm{ICR}_{4}\right)$. $\mathrm{ICS}_{1}$ has, in fact, a median value of 5.240 (70 cases $>1$ ), while $\mathrm{ICR}_{2}$ has a value of 2.023 (68 cases > 1); $\mathrm{ICR}_{3}$ has a median value of 2.277 ( 49 cases $>1$ ), while $\mathrm{ICR}_{4}$ has a value of 0.930 ( 37 cases $>1$ ). The analysis shows that the firms have financial difficulties in terms of paying debt services; the analysis conducted by applying traditional DSCRs ( $\mathrm{ICR}_{1}$ and $\mathrm{ICR}_{2}$ ) shows higher results if compared with DSCRs calculated with a financial approach $\left(\mathrm{ICR}_{3}\right.$ and $\left.\mathrm{ICR}_{4}\right)$. The analysis also shows that the parameters are characterized by skewness and kurtosis. We then test the normality of the distributions of all the significant considered parameters (income and financial margins, DSCRs, income ratios and IRRs). The Kolmogorov-Smirnov D Statistic (KSD) shows that several values do not follow the normal distribution, as in several researches in which the non-normality of the distribution of financial ratios is verified (Ezzamel et al., 1987). Applying KSD, we reject the null hypothesis $(0.001$ significance level) of a normal distribution for EBITDA, OCF, UFCF, FCFE, ICR $1, \mathrm{ICR}_{3}$ and $\mathrm{ICR}_{4}$; for EBIT, PROFIT and $\mathrm{ICR}_{4}$, we accept the null hypothesis of a normal distribution.

The correlation calculated with the parametric approach, using the Pearson statistic (Table 2), shows significant correlations between income margins and $\mathrm{CF} / \mathrm{OCF}$ only as financial margins, with a high significance $(1.00 \%)$.

$\underline{\text { Table 1. Descriptive statistics }}$

\begin{tabular}{|c|c|c|c|c|c|c|c|c|c|c|}
\hline \multirow[b]{2}{*}{ Parameters } & \multicolumn{2}{|l|}{ N. } & \multirow{2}{*}{$\begin{array}{l}\text { N. } \\
\text { Median }\end{array}$} & \multirow{2}{*}{$\begin{array}{l}\text { N. } \\
\text { S. Dev. }\end{array}$} & \multicolumn{2}{|c|}{ Skewness } & \multicolumn{2}{|c|}{ Kurtosis } & \multicolumn{2}{|l|}{ Values } \\
\hline & Stat & Mean & & & Stat & S. Dev & Stat & S. Dev & $\geq 0$ & $\geq 0$ \\
\hline EBITDA & 85 & 89,212 & 84,221 & 12,582 & -0.250 & 1.002 & -0.648 & 1.923 & 79 & 6 \\
\hline EBIT & 85 & 70,332 & 65,228 & 11,533 & -0.26 & 3.985 & -0.596 & 2.326 & 72 & 13 \\
\hline PROFIT & 85 & 45,209 & 48,122 & 9,268 & -0.652 & 2.621 & -0.250 & 2.002 & 50 & 35 \\
\hline $\mathrm{CF}$ & 85 & 47,336 & 44,252 & 4,289 & 0.453 & 0.980 & 0.341 & 0.980 & 80 & 5 \\
\hline OCF & 85 & 38,556 & 37,950 & 6,889 & -0.623 & 3.331 & 0.372 & 2.890 & 55 & 30 \\
\hline UFCF & 85 & $-1,250$ & 6,859 & 12,687 & -1.089 & 1.092 & 0.889 & 2.953 & 45 & 40 \\
\hline FCFE & 85 & $-12,338$ & $-8,532$ & 1,532 & -2.327 & 4.001 & 0.958 & 0.982 & 37 & 48 \\
\hline $\mathrm{ICR}_{1}$ & 85 & 5.240 & 3.220 & 2.661 & 6.732 & 0.322 & 7.988 & 0.022 & $79(70>1)$ & 6 \\
\hline $\mathrm{ICR}_{2}$ & 85 & 3.003 & 2.023 & 3.207 & 2.622 & 0.962 & 2.782 & 0.087 & $72(68>1)$ & 13 \\
\hline $\mathrm{ICR}_{3}$ & 85 & 2.021 & 2.227 & 1.360 & 9.037 & 0.898 & 2.322 & 0.276 & $55(49>1)$ & 30 \\
\hline $\mathrm{ICR}_{4}$ & 85 & 1.121 & 0.930 & 2.702 & -2.262 & 0.840 & 7.333 & 0.262 & $45(37>1)$ & 40 \\
\hline
\end{tabular}

Source: Our processing of directly collected data 
Mattia Iotti and Giuseppe Bonazzi / American Journal of Applied Sciences 11 (7): 1135-1151, 2014

Table 2. Correlation between income and financial margins-parametric approach (Corr. Pearson)

\begin{tabular}{|c|c|c|c|c|c|c|c|c|}
\hline & & EBITDA & EBIT & $\Pi^{\mathrm{pT}^{\mathrm{T}}}$ & $\mathrm{CF}$ & $\mathrm{OCF}$ & UFCF & FCFE \\
\hline \multirow[t]{3}{*}{ EBITDA } & Corr. Pearson & 1 & 0.791 & $0.831 * *$ & $0.625 * *$ & $0.452 * *$ & -0.021 & $\begin{array}{l}-0.098 \\
\end{array}$ \\
\hline & (sig. (2-tailed) & & 0.000 & 0.000 & 0.000 & 0.008 & 0.830 & 0.563 \\
\hline & $\mathrm{N}$ & & 85 & 85 & 85 & 85 & 85 & 85 \\
\hline \multirow[t]{3}{*}{ EBIT } & Corr. Pearson & $0.791 * *$ & 1 & $0.355^{* *}$ & $0.459 * *$ & $0.350 *$ & 0.100 & 0.125 \\
\hline & Sig. (2-tailed) & 0.000 & & 0.043 & 0.007 & 0.046 & 0.396 & 0.470 \\
\hline & $\mathrm{N}$ & 85 & & 85 & 85 & 85 & 85 & 85 \\
\hline \multirow[t]{3}{*}{$\Pi^{\mathrm{p}^{\mathrm{T}}}$} & Corr. Pearson & $0.831 * *$ & $0.355^{*}$ & 1 & 0.220 & $0.349 *$ & 0.225 & 0.234 \\
\hline & Sig. (2-tailed) & 0.000 & 0.043 & & 0.201 & 0.046 & 0.199 & 0.193 \\
\hline & $\mathrm{N}$ & 85 & 85 & & 85 & 85 & 85 & 85 \\
\hline \multirow[t]{3}{*}{$\mathrm{CF}$} & Corr. Pearson & $0.625^{*}$ & $0.459 * *$ & 0.220 & 1 & $0.720 * *$ & 0.201 & 0.250 \\
\hline & Sig. (2-tailed) & 0.000 & 0.007 & 0.201 & & 0.000 & 0.220 & 0.165 \\
\hline & $\mathrm{N}$ & 85 & 85 & 85 & & 85 & 85 & 85 \\
\hline \multirow[t]{3}{*}{$\mathrm{OCF}$} & Corr. Pearson & $0.0452 *$ & $0.350^{*}$ & $0.349^{*}$ & $0.720 *$ & 1 & $0.690 *$ & $0.621 *$ \\
\hline & Sig. (2-tailed) & 0.008 & $0.046^{*}$ & $0.046^{*}$ & 0.000 & & 0.000 & 0.000 \\
\hline & $\mathrm{N}$ & 85 & 85 & 85 & & 85 & 85 & 85 \\
\hline \multirow[t]{3}{*}{ UFCF } & Corr. Pearson & 0.021 & 0.100 & 0.225 & 0.201 & $0.690 * *$ & 1 & $0.991 * *$ \\
\hline & Sig. (2-tailed) & 0.830 & 0.396 & 0.199 & 0.220 & 0.000 & & 0.000 \\
\hline & $\mathrm{N}$ & 85 & 85 & 85 & 85 & 85 & & 85 \\
\hline \multirow[t]{3}{*}{ FCFE } & Corr. Pearson & -0.98 & 0.125 & 0.234 & 0.250 & $0.621 * *$ & $0.991 * *$ & 1 \\
\hline & Sig. (2-tailed) & 0.563 & 0.470 & 0.193 & 0.165 & 0.000 & 0.000 & \\
\hline & $\mathrm{N}$ & 85 & 85 & 85 & 85 & 85 & 85 & \\
\hline
\end{tabular}

**. The correlation is significant at the 0.01 level (two-tailed); *. the correlation is significant at the 0.05 level (two-tailed)

The correlations between income margins and UFCF and FCFE are not statistically significant. Given that the reduced sample size of 85 observations is also considered a nonparametric approach to correlations (Spearman's $\rho$ ), data (Table 3) confirm the conclusions of the approach with a parametric correlation, increasing, however, the significance of some correlations.

The data analyzed in absolute terms, considering intermediate income margins (EBITDA and EBIT) and PROFIT $\left(\rho^{\mathrm{pT}}\right)$, show a higher number of positive values (79, 72 and 50, respectively, of 85 observations) compared to financial operating margins $(\mathrm{CF}, \mathrm{OCF}$ and UFCF) and financial flow for equity holders (FCFE), respectively, with $80,55,45$ and 37 positive values. The comparison between income margins and financial margins is performed by evaluating the significance of the difference between means (Table 4), calculating Student's $t$ value for paired samples. The analysis considers seven comparisons, including three with EBITDA and financial margins, three with EBIT and financial margins and one between PROFIT and FCFE.

The pairwise comparisons with a parametric approach show, with the exception of the comparison between EBIT and OCF, that in all comparisons, we can reject the null hypothesis of equality between the means with a two-sided test with significance at $1.00 \%$.

The pairwise comparison with a nonparametric approach (Table 5), applied in regard to the small sample size, again highlights, except for the comparison between EBIT and OCF, that in all comparisons, we can reject the null hypothesis of equality between the means using a two-sided test with significance at $1.00 \%$ in five cases and with significance at $5.00 \%$ in one case.

The analysis of the ICR shows, for the sample firms, the sustainability assessment carried out through ICR calculated with an economic approach, even if these are the most frequently applied ICRs by firms and banks. The analysis shows that it could be preferable to apply the indexes suggested in the article, calculated with a financial approach, so that results are able to express more correctly the firm's capacity to pay the cost of debt. Sustainability evaluations of the cost of debt are done by applying ICRs; this evaluation is importance for firms looking to prevent financial crisis. Banks could usefully apply ICRs to assess the creditworthiness of firms in the sector and particularly against the current state of reduced bank lending (credit crunch), having that assessment of ICRs could offer a significant applied interest. ICRs calculated using an income approach, taking EBITDA and EBIT as the numerator, then expressing $\mathrm{ICR}_{1}$ and $\mathrm{ICR}_{2}$, have average values of 5.240 and 3.003, respectively; ICRs calculated with a financial approach (OCF and UFCF as the numerator) are $\mathrm{ICR}_{3}$ and $\mathrm{ICR}_{4}$ and have average values of 2.021 and 1.121, respectively. The comparison of the significance of differences between ICRs calculated with an income and a financial approach is carried out by evaluating the significance of the difference between the means (Table 6) using the Student's t statistic for paired samples. 
Mattia Iotti and Giuseppe Bonazzi / American Journal of Applied Sciences 11 (7): 1135-1151, 2014

Table 3. Correlation between income and financial margins - not parametric approach (Spearman's $\rho$ )

\begin{tabular}{|c|c|c|c|c|c|c|c|c|}
\hline & & EBITDA & EBIT & $\Pi^{\mathrm{pT}^{\mathrm{T}}}$ & $\mathrm{CF}$ & OCF & UFCF & FCFE \\
\hline \multirow[t]{3}{*}{ EBITDA } & Corr. $\rho$ specarman & 1 & $0.793 * *$ & $0.620 * *$ & $0.921 * *$ & $0.618 * *$ & 0.71 & 0.024 \\
\hline & Sig. (2-tailed) & & 0.000 & 0.000 & 0.000 & 0.000 & 0.696 & 0.887 \\
\hline & $\mathrm{N}$ & & 85 & 85 & 85 & 85 & 85 & 85 \\
\hline \multirow[t]{3}{*}{ EBIT } & Corr. $\rho$ specarman & $0.793^{* *}$ & 1 & $0.801 * *$ & $0.785 * *$ & 0.230 & 0.211 & 0.234 \\
\hline & Sig. (2-tailed) & 0.000 & & 0.000 & 0.000 & 0.221 & 0.235 & 0.208 \\
\hline & $\mathrm{N}$ & 85 & & 85 & 85 & 85 & 85 & 85 \\
\hline \multirow[t]{3}{*}{$\Pi^{\mathrm{pT}^{\mathrm{T}}}$} & Corr. $\rho$ specarman & $0.620^{* *}$ & $0.801 * *$ & 1 & 0.021 & 0.336 & 0.205 & $0.341 *$ \\
\hline & Sig. (2-tailed) & 0.000 & 0.000 & & 0.877 & 0.053 & 0.238 & 0.049 \\
\hline & $\mathrm{N}$ & 85 & 85 & & 85 & 85 & 85 & 85 \\
\hline \multirow[t]{3}{*}{$\mathrm{CF}$} & Corr. $\rho$ specarman & $0.921 * *$ & $0.785^{* *}$ & 0.21 & 1 & 0.201 & 0.032 & -0.025 \\
\hline & Sig. (2-tailed) & 0.000 & 0.000 & 0.877 & & 0.242 & 0.850 & 0.889 \\
\hline & $\mathrm{N}$ & 85 & 85 & 85 & & 85 & 85 & 85 \\
\hline \multirow[t]{3}{*}{ OCF } & Corr. $\rho$ specarman & $0.618 * *$ & 0.230 & 0.336 & 0.201 & 1 & $0.642 * *$ & $0.587 * *$ \\
\hline & Sig. (2-tailed) & 0.000 & 0.221 & 0.053 & 0.242 & & 0.000 & 0.000 \\
\hline & $\mathrm{N}$ & 85 & 85 & 85 & 85 & & 85 & 85 \\
\hline \multirow[t]{3}{*}{ UFCF } & Corr. $\rho$ specarman & 0.071 & 0.211 & 0.205 & 0.32 & $0.642 * *$ & 1 & $0.985 * *$ \\
\hline & Sig. (2-tailed) & 0.696 & 0.235 & 0.238 & 0.850 & 0.000 & & 0.000 \\
\hline & $\mathrm{N}$ & 85 & 85 & 85 & 85 & 85 & & 85 \\
\hline \multirow[t]{3}{*}{ FCFE } & Corr. $\rho$ specarman & 0.024 & 0.234 & $0.341 *$ & -.0 .25 & $0.587 * *$ & $0.985 * *$ & 1 \\
\hline & Sig. (2-tailed) & 0.887 & 0.208 & 0.049 & 0.889 & 0.000 & 0.000 & \\
\hline & $\mathrm{N}$ & 85 & 85 & 85 & 85 & 85 & 85 & \\
\hline
\end{tabular}

**.the correlation is significant at the 0.01 level (two-tailed); *. The correlation is significant at the 0.05 level (two-tailed)

Table 4. Comparison of economic and financial margins-parametric approach for paired samples (t-Student)

\begin{tabular}{|c|c|c|c|}
\hline \multirow[b]{2}{*}{ Couples of value } & \multicolumn{3}{|c|}{ Values and statistics } \\
\hline & Mean & $\mathrm{t}$ & Sig. (2-tailed) \\
\hline Couple 1 EBITDA-CF & 4.911 & 8.915 & $0.000 * *$ \\
\hline Couple 2 EBITDA-OCF & 3.402 & 3.680 & $0.001 * *$ \\
\hline Couple 3 EBITDA-UFCF & 7.127 & 5.685 & $0.000 * *$ \\
\hline Couple 4 EBIT-CF & -2.021 & -5.039 & $0.000 * *$ \\
\hline Couple 5 EBIT-OCF & 0.362 & 0.107 & 0.916 \\
\hline Couple 6 EBIT_UFCF & 6.122 & 4.090 & $0.000 * *$ \\
\hline Couple 7 PROFIT-FCFE & 5.250 & 3.349 & $0.002 * *$ \\
\hline
\end{tabular}

**. Test is significant at the 0.01 level (two-tailed), *. Test is significant at the 0.05 level (two-tailed), Source: Our processing of directly collected data

Table 5. Comparison of economic and financial margins-not parametric approach for paired samples (T-Wilcoxon)

\begin{tabular}{lrlll}
\hline Couple & T-Wilcoxon & T-Wilcoxon & & \\
\hline Couple 1 EBITDA-CF & For paired sample stat. & for paired sample stand. Stat & Observ. & Sig. (2-tailed) \\
Couple 2 EBITDA-OCF & 67 & -3.941 & 85 & $0.000^{* *}$ \\
Couple 3 EBITDA-UFCF & 100 & -3.377 & 85 & $0.001^{* *}$ \\
Couple 4 EBIT-CF & 538 & -4.932 & 85 & $0.000^{* *}$ \\
Couple 5 EBIT-OCF & 304 & 4.112 & 85 & $0.000^{* *}$ \\
Couple 6 EBIT-UFCF & 76 & 0.111 & 85 & $0.912^{*}$ \\
Couple 7 PROFIT-FCFE & 132 & -3.787 & 85 & $0.000^{* *}$ \\
\hline
\end{tabular}

**.Test is significant at the 0.01 level (two-tailed), *. Test is significant at the 0.05 level (two-tailed); Source: Our processing of directly collected data 
Table 6. Comparison of ICRs with economic and financial approach-parametric approach for paired samples (t-Student)

\begin{tabular}{|c|c|c|c|}
\hline \multirow[b]{2}{*}{ Couples of value } & \multicolumn{3}{|c|}{ Values and statistics } \\
\hline & Mean & $\mathrm{t}$ & Sig. (2-tailed) \\
\hline Couple $1 \mathrm{ICR}_{1}-\mathrm{ICR}_{3}$ & 8.0019 & 3.022 & $0.005^{* *}$ \\
\hline Couple $2 \mathrm{ICR}_{1}-\mathrm{ICR}_{4}$ & 14.4088 & 4.051 & $0.000 * *$ \\
\hline Couple $3 \mathrm{ICR}_{2}-\mathrm{ICR}_{3}$ & 1.9018 & 1.209 & 0.172 \\
\hline Couple $4 \mathrm{ICR}_{2}-\mathrm{ICR}_{4}$ & 7.9912 & 4.705 & $0.000 * *$ \\
\hline
\end{tabular}

**. Test is significant at the 0.01 level (2-tailed); *. Test is significant at the 0.05 level (2-tailed); Source: Our processing of directly collected data

A nonparametric approach was also applied, given the limited sample size, using the statistic of Wilcoxon (Wilcoxon Matched-Pairs Signed-Ranks Test) for paired samples (Table 7). The analysis is articulated considering four comparisons and shows that the comparison in pairs with a parametric approach highlights, with the exception of the comparison between $\mathrm{ICR}_{2}$ and $\mathrm{ICR}_{3}$, that it is possible to reject the null hypothesis of equality between means by applying a two-sided test with significance at $1.00 \%$ in two cases and at $5.00 \%$ in one case.

A nonparametric approach was also applied, given the limited sample size, using the statistic of Wilcoxon (Wilcoxon Matched-Pairs Signed-Ranks Test) for paired samples (Table 7), which confirms the results of the analysis using a parametric approach.

\section{REGRESSION ANALYSIS}

The regression analysis aims to quantify the causal relationship between a variable to be explained (the dependent variable) and one or more explanatory variables (independent variables). The objective of the analysis is to identify the capacity of the independent variables to explain the variation of the dependent variable and their impact on the dependent variable. In the article, we would quantify the relation between financial and economic flow; the research is particularly interested in analyzing if there was a relation between a financial measure such as FCFE, which expresses the amount of cash available for equity holders and some independent variables. To achieve this aim, we compare the explanatory capacity of two linear regression models. The first model (economic model), expressed in Equation 9, considers $\mathrm{FCFE}_{\mathrm{t}}$, which expresses the amount of cash available for equity holders, as an independent variable in a given time $(t)$. In the first regression models, the constant term is $\alpha, \mathrm{T}$ is turnover (sales/invested capital), I_days is the duration in days of the cycle of the warehouse, AR_days is the duration in days of the average extension to customers, AP_days is the duration in days of the average extension from suppliers, DER is debt equity ratio (debt/equity), SIZE is the size of the capital invested in euro (total assets) and ROS is return on sales (EBIT/sales). The model then considers EBITDA as an explanatory variable, considered in values for the years $t$ and $t-1$ (EBITDA $A_{t}$ and EBITDA $_{t-1}$, respectively). At the same time, EBIT and PROFIT are considered explanatory variables, considered in their values for years $t$ and $t-1$, giving then another four explanatory variables $\left(\right.$ EBIT $_{t}$ and EBIT $_{t-1}$, PROFIT $_{t}$ and PROFIT $_{t-1}$ ). The model could be expressed as follows:

$$
\begin{aligned}
& \text { FCFE }_{\mathrm{t}}=\alpha+\beta_{1} \mathrm{~T}+\beta_{2} \mathrm{I} \_ \text {days }+ \\
& \beta_{3} \mathrm{AR} \_ \text {days }+\beta_{4} \mathrm{AP} \_ \text {days }+ \\
& +\beta_{5} \text { DER }+\beta_{6} \mathrm{SIZE}+\beta_{7} \text { ROS }+ \\
& \beta_{8} \mathrm{EBITDA}_{\mathrm{t}}+\beta_{9} \mathrm{EBIT}_{\mathrm{t}}+ \\
& +\beta_{10} \mathrm{PROFIT}_{\mathrm{t}}+\beta_{11} \mathrm{EBITDA}_{\mathrm{t}-1}+ \\
& \beta_{12} \mathrm{EBIT}_{\mathrm{t}-1}+\beta_{13} \text { PROFIT }_{\mathrm{t}-1}+\varepsilon
\end{aligned}
$$

The model seeks to explain whether the intermediate income margins can be considered as adequate explanatory variables of the amount of cash available for equity holders in the tomato industry.

The economic model, as expressed in Equation 9 and analyzed in Table 8, assumes a significant statistical capacity to explain $\mathrm{FCFE}_{\mathrm{t}}$ values. The $\mathrm{F}$ statistic for the considered model has high significance $(F=0.000)$; adjusted $R^{2}$ has the value 0.751 , expressing the sufficient capacity of the model to explain a great part of the variability of $\mathrm{FCFE}_{\mathrm{t}}$; the statistic DW is 2.652; and the majority of the variables are significant. Income margins

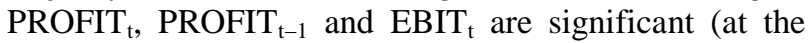
0.001 and 0.05 levels), while EBITDA ${ }_{t}$, EBITDA $_{t-1}$ and EBIT $_{t-1}$ are not significant. In the model, the coefficients of TURNOVER, I_days, DER and ROS, act as a positive on FCFE, while AR_days and SIZE have a negative sign. It is interesting to note that FCFE is mainly influenced by intermediate income margins of the year, while intermediate income margins of the previous year are less important as explanatory variables. 
Table 7. Comparison of ICRs with economic and financial approach-parametric approach for paired samples (t-Student)

\begin{tabular}{lllll}
\hline & T-Wilcoxon for & T-Wilcoxon for & & \\
Coppia & paired sample stat. & paired sample stant. stat. & Observ. & Sig. (2-tailed) \\
\hline Couple 1 ICR $1-\mathrm{ICR}_{3}$ & 15 & -3.479 & 85 & $0.000^{* *}$ \\
Couple 2 ICR $-\mathrm{ICR}_{4}$ & 11 & -4.881 & 85 & $0.000^{* *}$ \\
Couple 3 $\mathrm{ICR}_{2}-\mathrm{ICR}_{3}$ & 250 & -1.154 & 85 & $0.256^{*}$ \\
Couple 4 $\mathrm{ICR}_{2}-\mathrm{ICR}_{4}$ & 60 & -4.078 & 85 & $0.000^{* *}$ \\
\hline
\end{tabular}

**. Test is significant at the 0.01 level (2-tailed); *. Test is significant at the 0.05 level (2-tailed); Source: Our processing of directly collected data

Table 8. Extract of the multiple regression model that shows the impact on FCFEt of economic independent variables-economic model Equation 9

\begin{tabular}{|c|c|c|c|c|c|}
\hline \multirow[b]{2}{*}{ Model } & \multicolumn{2}{|c|}{ Unstandardized coefficient } & \multicolumn{2}{|c|}{ Standardized coefficient } & \multirow[b]{2}{*}{ Sig. } \\
\hline & $\mathrm{B}$ & Std. Error & Beta & $\mathrm{T}$ & \\
\hline$(\alpha$ Constant $)$ & -0.2156 & 0.033 & - & 6.702 & $0.000 * * *$ \\
\hline TURNOVER & 0.1912 & 0.024 & 0.402 & 7.012 & $0.000 * * *$ \\
\hline I_DAYS & 0.0085 & 0.025 & 0.135 & 2.101 & $0.039 *$ \\
\hline AR_DAYS & 0.0788 & 0.060 & -0.028 & -2.065 & $0.042 *$ \\
\hline AP_SAYS & 0.0012 & 0.090 & 0.41 & 2.031 & $0.045^{*}$ \\
\hline DER & 0.0136 & 0.101 & 0.191 & 2.851 & $0.006^{*}$ \\
\hline SIZE & 0.0101 & 0.256 & -0.065 & -2.078 & $0.040^{*}$ \\
\hline ROS & 0.1564 & 0.058 & 0759 & 12.320 & $0.000 * *$ \\
\hline EBITDA $_{t}$ & -0.1198 & 0.060 & 0.780 & 1.120 & 0.190 \\
\hline $\mathrm{EBIT}_{\mathrm{t}}$ & 0.1280 & 0.018 & 0.129 & 2.320 & $0.028 *$ \\
\hline PROFIT $_{t}$ & 0.0958 & 0.019 & 0.121 & 4.698 & $0.000 * *$ \\
\hline EBITDA $_{t-1}$ & 0.0846 & 0.021 & 0.101 & 0.885 & 0.230 \\
\hline $\mathrm{EBIT}_{\mathrm{t}-1}$ & 0.1165 & 0.036 & 0.039 & 0.490 & 0.551 \\
\hline PROFIT $_{t-1}$ & 0.1182 & 0.098 & 0.050 & 2.110 & $0.040^{*}$ \\
\hline
\end{tabular}

Economic model, Equation 9. Dependent variable: $\mathrm{FCEF}_{\mathrm{t}} ; * * *$. The relation is significant at the 0.001 level (2-tailed); **. The relation is significant at the 0.01 level (2-tailed); *. The relation is significant at the 0.05 level (2-tailed); Source: Our processing of directly collected data

The second model applied in the article has a financial approach, as expressed in Equation (10) and considers $\mathrm{FCFE}_{\mathrm{t}}$ as an independent variable in a given time (t), having $\alpha$ as a constant term and other independent variables that are the following: T (turnover), I_days, AR_days, AP_days, DER, SIZE (total assets) and ROS, as considered in model (9). The model then considers financial margins as explanatory variables for FCFE, considering $\mathrm{CF}$ in values for the years $\mathrm{t}$ and $\mathrm{t}-1\left(\mathrm{CF}_{\mathrm{t}}\right.$ and $\mathrm{CF}_{\mathrm{t}-1}$, respectively). At the same time, OCF and UFCF are considered explanatory variables, considered in their values for years $\mathrm{t}$ and $\mathrm{t}-1$, giving then another four explanatory variables $\left(\mathrm{OCF}_{\mathrm{t}}\right.$ and $\mathrm{OCF}_{\mathrm{t}-1}, \mathrm{UFCF}_{\mathrm{t}}$ and $\left.\mathrm{UFCF}_{\mathrm{t}-1}\right)$. We express the model as follows:

$$
\begin{aligned}
& \mathrm{FCFE}_{\mathrm{t}}=\alpha+\beta_{1} \mathrm{~T}+\beta_{2} \mathrm{I} \_ \text {days }+ \\
& \beta_{3} \mathrm{AR} \_ \text {days }+\beta_{4} \mathrm{AP} \_ \text {days }+\beta_{5} \mathrm{DER}+ \\
& +\beta_{6} \mathrm{SIZE}+\beta_{7} \mathrm{ROS}+\beta_{8} \mathrm{CF}_{\mathrm{t}}+ \\
& \beta_{9} \mathrm{OCF}_{\mathrm{t}}+\beta_{10} \mathrm{UFCF}_{\mathrm{t}}+\beta_{11} \mathrm{CF}_{\mathrm{t}-1}+ \\
& +\beta_{12} \mathrm{OCF}_{\mathrm{t}-1}+\beta_{13} \mathrm{UFCF}_{\mathrm{t}-1}+\varepsilon
\end{aligned}
$$

The idea underlying this second model is that it could be possible to explain actual FCFE (at a given time, $t$ ) considering as explanatory variables the actual financial margins ( $\mathrm{CF}, \mathrm{OCF}$ and $\mathrm{UFCF}$ ) and their respective values considered at time $\mathrm{t}-1\left(\mathrm{CF}_{\mathrm{t}}, \mathrm{OCF}_{\mathrm{t}}\right.$ and $\left.\mathrm{UFCF}_{\mathrm{t}}\right)$.

This second model does not consider income margins (as an economic model) but considers financial margins as explanatory variables. The financial model as expressed in equation (10) and analyzed in Table 9 assumes a high statistical capacity to explain FCFE $_{t}$ values. The F statistic for the considered model has high significance $(F=0.000)$; adjusted $R^{2}$ has the value 0.955 , expressing the capacity of the model to explain a great part of the variability of $\mathrm{FCFE}_{\mathrm{t}}$; the statistic DW is 2.125; and all the variables are significant. The financial margins of the year, $\mathrm{CF}_{\mathrm{t}}, \mathrm{OCF}_{\mathrm{t}}$ and $\mathrm{UFCF}_{\mathrm{t}}$, are highly significant (significant at the 0.001 level) and at the same time, the financial margins of the previous year, $\mathrm{CF}_{\mathrm{t}-1}$, $\mathrm{OCF}_{\mathrm{t}-1}$ and $\mathrm{UFCF}_{\mathrm{t}-1}$, are relatively significant (significant at the 0.01 and 0.05 levels). 
Mattia Iotti and Giuseppe Bonazzi / American Journal of Applied Sciences 11 (7): 1135-1151, 2014

Table 9. Extract of the multiple regression model that shows the impact on FCFEt of economic independent variables - economic model Equation 10

\begin{tabular}{|c|c|c|c|c|c|}
\hline \multirow[b]{2}{*}{ Model } & \multicolumn{2}{|c|}{ Unstandardized coefficient } & \multicolumn{2}{|c|}{ Standardized coefficient } & \multirow[b]{2}{*}{ Sig. } \\
\hline & $\mathrm{B}$ & Std. error & Beta & $\mathrm{T}$ & \\
\hline$(\alpha$ constant $)$ & -0.2156 & 0.033 & - & 6.702 & $0.000 * * *$ \\
\hline TURNOVER & 0.1912 & 0.024 & 0.402 & 7.012 & $0.000 * * *$ \\
\hline I_DAYS & 0.0085 & 0.250 & 0.135 & 2.101 & $0.039 *$ \\
\hline$\overline{A R}$ DAYS & 0.0788 & 0.060 & -0.028 & -2.065 & $0.042 *$ \\
\hline AP_SAYS & 0.0012 & 0.090 & 0.041 & 2.031 & $0.045^{*}$ \\
\hline DER & 0.0136 & 0.101 & 0.191 & 2.851 & $0.006^{* *}$ \\
\hline SIZE & 0.0101 & 0.256 & -0.065 & -2.078 & $0.040^{*}$ \\
\hline ROS & 0.1564 & 0.058 & 0.759 & 12.320 & $0.000 * *$ \\
\hline $\mathrm{CF}_{\mathrm{t}}$ & 0.1198 & 0.060 & 0.780 & 2.140 & $0.038^{*}$ \\
\hline $\mathrm{OCF}_{\mathrm{t}}$ & 0.1280 & 0.018 & 0.109 & 7.023 & $0.000 * *$ \\
\hline $\mathrm{UFCF}_{\mathrm{t}}$ & 0.0958 & 0.019 & 0.121 & 5.698 & $0.000 * * *$ \\
\hline $\mathrm{CF}_{\mathrm{t}-1}$ & 0.0846 & 0.021 & 0.145 & 2.885 & $0.006 * *$ \\
\hline $\mathrm{OCF}_{\mathrm{t}-1}$ & 0.1165 & 0.036 & 0.89 & 4.490 & $0.000 * * *$ \\
\hline $\mathrm{UFCF}_{\mathrm{t}-1}$ & 0.1182 & 0.980 & 0.090 & 4.110 & $0.000 * * *$ \\
\hline
\end{tabular}

Financial model, Equation 10. Dependent variable: $\mathrm{FCFE}_{\mathrm{t}}$ ***. The relation is significant at the 0.001 level (2-tailed); **. The relation is significant at the 0.01 level (2-tailed); *. The relation is significant at the 0.05 level (2-tailed); Source: Our processing of directly collected data

As in the first model, the coefficients of TURNOVER, I_days, DER and ROS, act as a positive on FCFE, while AR_days and SIZE have a negative sign. It is interesting to note that FCFE is highly influenced by financial margins of the year, while intermediate financial margins of the previous year are less important as explanatory variables.

\section{DISCUSSION}

Tomato production areas in Italy characterize many regions, particularly Campania and Basilicata in the southern part of the country and Emilia-Romagna and the lower part of Lombardia in the north; both territories are characterized by the tomato production and processing industry, specializing in concentrated tomato, canned tomato, juice and tomato pulp. These products are destined, in large part, for foreign markets, so Italy is the world's leading exporter of processed tomatoes. Even in a positive market scenario, the structure of the sector is, however, subject to profound changes in the geography of production, even considering the tomato processing trends worldwide. In fact, several emerging producer countries, including China, have increased their production of tomato in recent years, given important changes in the dynamics of international trade in quantitative and even qualitative terms. The surface of tomato production in Italy had a decrease of $11.80 \%$ in the period from 2007 to 2011; this contraction is greater in tomatoes for food consumption $(-17.06 \%)$ compared with tomatoes for the processing industry $(-10.49 \%)$. In the same period, there was an increase in the production of tomatoes for processing $(0.93 \%$ for production and $1.33 \%$ for harvesting), with an increase in average yields per hectare, while tomatoes for food consumption had a decrease of $16.06 \%$ in production and $16.75 \%$ in harvesting. The concentration of the tomato production industry is particularly high in two main geographical areas. The most important production area is in the northern part of Italy, including the regions of EmiliaRomagna, Lombardia, Veneto and Piemonte and produced 2.4 million tons in 2011 (45\% of the domestic production of tomatoes). The second area is located in the southern regions of Campania, Puglia, Calabria and Basilicata, with a production of 2.3 million tons in 2011 (43\% of domestic production). The transformation of the tomato industry has taken place generally in plants adjacent to the areas of production because of specific strategic purposes particularly related to cost reduction; the reductions in transportation costs of the raw materials from production areas to processing plants have, in fact, a great part in this concentration process of production plants. In southern Italy, 96 tomato processing firms operated in 2011, of which 79 are limited companies, 12 are nonlimited companies and sole proprietorships and 5 are cooperative firms. In northern Italy (EmiliaRomagna, Lombardia, Veneto and Piemonte regions), the tradition of processing tomatoes has its origins in the late 19th century with the rise of the canning industry in the province of Parma. In these territories, 25 processing firms are active, of which 18 are limited companies, 6 
are cooperatives and 1 is a nonlimited company; EmiliaRomagna prevails among the three major production regions of northern Italy, with 16 processing firms. The firms in northern Italy are in some cases related to family groups that have had ownership and control of the firms for several generations. In other cases, the firms operate as cooperative enterprises, such as producer cooperatives (second-level cooperatives). The distribution of the processed tomato is, in large part, through the channel of large supermarket chains; these retailers use their bargaining power to impose low trading prices of the finished products on the processing industry, even applying unfavorable conditions to dilate the average time payment for suppliers (i.e., processing firms). Moreover, processing firms suffer from the transformation of a frequently nondifferentiable production, even with modest brand recognition among consumers. The low level of consumer loyalty reduces the bargaining power of processing firms in the face of distribution firms. Moreover, Regulation (EC) No. $1182 / 2007$, on the reform of the fruits and vegetables sector, has intervened in support of aid for tomatoes that, in harmony with the rest of EU policy, introduces the decoupling of public aid. Article 5 of National Decree No. 1540/2007 lays down provisions for the implementation of the reform of the Common Agricultural Policy in the tomato sector; these rules show the guidelines for granting payment to support farm income. The rules were issued in 2008, with a transitional period until 2010, with a partial decoupling. It was defined as a three-year transitional period, followed by the 2011 implementation of the reform, even with reflections on the choices of public funds management, faced with a scenario of EU contribution in gradual decrease; this scenario has its implications in terms of the need to increase management efficiency of enterprises in the sector, especially in light of the CAP post-2013 period (Lombardi, Vernau, 2010). During this period, the price of processing tomatoes has increased in recent years, arriving at $€ 88$ per ton in 2011 , from $€ 80$ per ton in 2010 and $€ 70$ per ton in 2009 . Several firms in the sector have been so affected by situations of instability also because of an increase in the cost of raw materials, with effect on profitability and even on the firm's risk of bankruptcy. The firms in the tomato processing sector are characterized, as is shown in the analysis, by a high level of capital investment, in particular to finance investments in plants and machinery. These firms often require investments to achieve a high level of technical efficiency, to reduce costs of production and also to ensure food safety standards. Investment in capital equipment, however, needs to be covered with sources of capital that are retrieved with direct contribution of the entrepreneur, as equity capital, or acquiring new capital as debt. This capital requirement could cause financial difficulties, especially for small and medium enterprises, which are disadvantaged in the access to capital markets. For firms in the tomato processing industry sector, as considered in the article, the time lag that exists between the economic cycle and the financial cycle can lead to wrong strategic decisions, with the risk of default for many firms in the sector. In fact, in recent years, the processing companies of the sector have been characterized by a large number of corporate crises, which have also caused bankruptcy and liquidation. Many extraordinary restructuring plans were also performed to avoid firms' bankruptcy. On this topic, it is considered that the distribution of finished products is carried out by large retail chains; these firms use their bargaining power to impose trading prices of finished products that are unfavorable for processing firms, even increasing the average time of suppliers' payment. This strategic weakness is disadvantageous for bargaining the power of processing firms against large retailers, having negative effects in terms of market price and delays in credit payment. Data analysis of companies in the sector of industrial tomato processing is done based on data of public filings with the registrar of companies for the years 2007 to 2011 , on a sample of 17 firms, for a total of 85 years of data. Of the 17 sample firms, 1 is located in Piemonte, 2 in Lombardia and 14 in Emilia-Romagna; considering a total presence of 25 processing firms in the three areas mentioned above, the sample includes $68 \%$ of the processing firms of those territories. Of the eight firms not included in the sample, one is in the form of a nonlimited company, thus not presenting a public annual account at the registrar of companies; one firm is subject to a liquidation procedure, which makes it inactive; one firm has not made the 2011 annual account available; and five firms operate with a plurality of production that, for the tomato processing industry, makes their data not comparable with the firms included in the sample. The analysis of the sample firms first considers the asset data for 2011 (Table 10) of the annual balance sheet; these data are of interest because they express the high level of capital intensity required for the tomato processing activities of the firms in the sample, given the value of production $\left(\mathrm{TA}_{2011} / \mathrm{VP}_{2011}\right.$ average is $\left.98.89 \%\right)$; sector firms are capital-intensive, considering fixed assets and the working capital cycle. 
Mattia Iotti and Giuseppe Bonazzi / American Journal of Applied Sciences 11 (7): 1135-1151, 2014

Table 10. Balance sheet data of the sample firms (2011) - reclassification of the balance sheet with financial approach

\begin{tabular}{|c|c|c|c|c|c|c|}
\hline Value & $\begin{array}{l}\text { Average } \\
\text { Limited companies } \\
(€)\end{array}$ & $\begin{array}{l}\text { Average } \\
\text { Limited companies } \\
(\% \text { TA })\end{array}$ & $\begin{array}{l}\text { Average } \\
\text { cooperatives } \\
(€)\end{array}$ & $\begin{array}{l}\text { Average } \\
\text { cooperatives } \\
(\% \text { TA })\end{array}$ & $\begin{array}{l}\text { Average } \\
\text { total sample } \\
(€)\end{array}$ & $\begin{array}{l}\text { Average } \\
\text { total sample } \\
(\% \text { TA })\end{array}$ \\
\hline$\overline{\text { FA }}$ & $19,365,797$ & $3284 \%$ & $50,015,936$ & $39.42 \%$ & $28,380,543$ & $35.95 \%$ \\
\hline $\mathrm{WCi}^{\mathrm{a}}$ & $18,606,662$ & $31.55 \%$ & $43,755,789$ & $34.48 \%$ & $26,003,464$ & $32.94 \%$ \\
\hline WCar ${ }^{\mathrm{a}}$ & $17,541,636$ & $29.74 \%$ & $26,398,967$ & $20.88 \%$ & $20,176,145$ & $25.56 \%$ \\
\hline $\mathrm{WCo}^{\mathrm{a}}$ & $1,842,647$ & $3.12 \%$ & $4,407,957$ & $3.47 \%$ & $2,597,150$ & $3.29 \%$ \\
\hline $\mathrm{WC}^{\mathrm{aT}}$ & $37,990,945$ & $64.42 \%$ & $74,662,713$ & $58.84 \%$ & $48,776,759$ & $61.78 \%$ \\
\hline $\mathrm{L}$ & $1,617,743$ & $2.74 \%$ & $2,215,248$ & $1.75 \%$ & $1,793,479$ & $2.27 \%$ \\
\hline TA & $58,974,484$ & $100.00 \%$ & $126,893,897$ & $100.00 \%$ & $78,950,782$ & $100,00 \%$ \\
\hline $\mathrm{E}^{\mathrm{T}}$ & $16,467,915$ & $27.92 \%$ & $25,767,087$ & $20.31 \%$ & $19,202,966$ & $24.32 \%$ \\
\hline $\mathrm{DF}^{\mathrm{M}<12}$ & $14,374,151$ & $24.37 \%$ & $35,365,493$ & $27.87 \%$ & $20,548,075$ & $26.03 \%$ \\
\hline $\mathrm{DF}^{\mathrm{M}>12}$ & $10,604,670$ & $17.98 \%$ & $27,221,378$ & $21.45 \%$ & $15,491,937$ & $19.62 \%$ \\
\hline $\mathrm{DF}^{\mathrm{T}}$ & $24,978,821$ & $42.36 \%$ & $62,586,871$ & $49.32 \%$ & $36,040,012$ & $45.65 \%$ \\
\hline WCap ${ }^{s}$ & $12,515,537$ & $21.22 \%$ & $25,470,111$ & $20.07 \%$ & $16,325,706$ & $20.68 \%$ \\
\hline $\mathrm{WCo}^{\mathrm{s}}$ & $5,012,212$ & $8.50 \%$ & $13,069,827$ & $10.30 \%$ & $7,382,099$ & $9.35 \%$ \\
\hline $\mathrm{WC}^{\mathrm{sT}}$ & $17,527,748$ & $29.72 \%$ & $38,539,938$ & $30.37 \%$ & $23,707,804$ & $30.03 \%$ \\
\hline $\mathrm{D}^{\mathrm{T}}$ & $42,506,569$ & $72.08 \%$ & $101,126,809$ & $79.69 \%$ & $59,747,816$ & $75.68 \%$ \\
\hline TS & $58,974,484$ & $100.00 \%$ & $126,893,897$ & $100.00 \%$ & $78,950,782$ & $100.00 \%$ \\
\hline
\end{tabular}

Source: Our processing of directly collected data

The data of the sample show the importance of investment in fixed assets (35.95\% of TA) and in the inventories of working capital (32.94\% of TA). Tomato processing firms, in fact, require investment in land and buildings to store the finished products and in plants and machinery to process raw materials. In the sector, particularly important investments in plants are characterized by a high technological level (i.e., lines of sterilization and lines of packaging with high productivity) with the relevant cost per unit. These characteristics have an effect on increasing the capital needs to finance investment in improving the firm's efficiency. Trade receivables are also one of the major factors of asset investment (an average of $25.56 \%$ TA); the high capital absorption due to this factors of asset investment is determined by large retail chains, whose bargaining power causes an increase in average days of credit payments (trade receivables). To cover their financial needs, the firms in the sample use financial debts as the first source of capital, given the fact that $\mathrm{DF}^{\mathrm{M}<12}+\mathrm{DF}^{\mathrm{M}>12}$ is $45.65 \%$ of the TA, with a prevalence of loans maturing within 12 months (26.03\% of the TA) compared with loans maturing after 12 months (19.62\%); this high level of financial debt increases the financial dependence on the credit system and increases borrowing costs. Equity capital $\left(\mathrm{E}^{\mathrm{T}}\right)$ is, in fact, $24.32 \%$ of the $\mathrm{TA}$ and it is lower than $\mathrm{WC}^{\mathrm{PT}}$ that is equal to $30.03 \%$. The analyzed capital structure shows that firms in the sector acquire high debt levels to finance investments, given, in fact, that equity capital is the third source of capital. The analysis of the balance sheet in functional form confirms the prevalence of investment in fixed assets (53.10\% of NIC) and also highlights NWC $>0$, having a mean of NWC that is $46.90 \%$ of NIC; this characteristic of the balance sheet of the considered firms expresses the high level of capital absorption in the cycle of working capital (inventories plus trade receivables less accounts payable). The analysis then shows the capital requirement to finance NWC, having equity capital or financial debt as a source of capital; at the same time, what emerges is the usefulness of assessing the sustainability of financial debt and considering its cost, as well as the performance of equity capital compared with its expected return. The analysis shows that NFP is the first source of capital to finance NIC, where NFP is equal to $64.07 \%$ of NIC, while $\mathrm{E}^{\mathrm{T}}$ is equal to $35.03 \%$ of NIC. The analysis of the balance sheet in the functional form then confirms the dependence of tomato processing firms on financial debt and, consequently, the need for these companies to assess the sustainability of debt services. Further information on the typical characteristics of the firms in the sector results from the analysis of economic data (Table 11); the average value of VP amounts to $€ 71,448,071$ and the largest factor of cost is raw materials $(57.17 \%$ of VP), which is $54.22 \%$ for limited companies and $61.40 \%$ for cooperatives. The cost of services is $20.79 \%$ of VP, while labor costs are the third largest cost, with an incidence that is $11.63 \%$ of VP; EBITDA and EBIT are, respectively, 8.17 and $4.21 \%$ of VP. The balance of financial charge (SF) absorbs $1.72 \%$ of VP-that is, $40.86 \%$ of EBIT. It thus appears that a relevant part of the intermediate profit margins (EBITDA and EBIT) is absorbed by the cost of bank 
charges due the financial debt. The income statement data confirm the high impact of interest charges on the results of the firms in the sample. The net profit $\left(\Pi^{\mathrm{pT}}\right)$ is $€ 1,177,771$ on average, equal to $1.65 \%$ of $\mathrm{VP}$ value in the sample, a value that rises to $2.60 \%$ of VP in limited companies, while in cooperative firms, the value is only $0.28 \%$ of VP.

The financial data of considered firms permit the calculation of the financial statement that expresses cash flow availability due to the management cycle. The values of the financial statements of the companies thus calculated show an average CF that is $7.72 \%$ of VP; the average absorption of capital due to the cycle of working capital amounted to $€ 2,279,274$-that is, $3.19 \%$ of VPfrom which it follows that the average OCF is $€ 3,238,135$ (4.35\% of VP). It is then possible to note an important absorption of liquidity because of investments in fixed assets, given that an increase in FA determines a negative UFCF for $1.49 \%$ of VP, with absorption of cash equal to $6.02 \%$ of VP. This means that, on average, the sample firms are not able to cover the cost of debt without an increase in equity capital and/or increase in the level of financial debt; this necessity of coverage expresses a financial situation where, on average, FCFE $<0$, implying the impossibility to distribute dividends, if any and/or reimburse NFP.

The analysis of financial statements (Table 12) highlights some typical management characteristics of firms in the tomato food processing sector: (1) the dynamic of Working Capital (NWC) absorbs a significant amount of liquidity generated by operations (CF) as expressed by OCF values and (2) the investments in fixed assets further reduce financial margins available, making UFCF negative on average. Given the current situation of general economic crisis and the consequent difficulty in credit access, it could be useful to assess the sustainability of the business cycle, given the liquidity absorption highlighted by the firms' sample annual account data. To achieve this goal, we compare income margins with financial margins to assess whether there are correlations between these two types of values; moreover, we would quantify if there are significant differences between income and financial values. The analysis conducted in the article, expressing a comparison between income margins and financial margins, aims to identify whether there are statistically significant differences between economic and financial margins for the firms in the sample, given their characterization of high liquidity absorption in the financial cycle of fixed assets and working capital. This case is particularly relevant for the sector, where for the majority of firms, an increase in the value of Net Working Capital (NWC) could generate difficulties in applying an additional source of capital because of their reduced capacity to obtain bank loans. For the assessment of the sustainability of the business cycle, there are frequently applied margins that consider income values such as EBITDA and EBIT to approximate cash flow measurements. Moreover, it is necessary to express that these margins do not consider (1) the effect of the revenues to be collected from customers, (2) the purchases not paid to suppliers and (3) the change in values of inventories.

Table 11. Income statement data of the sample firms (2011) -reclassification of the income statement value added approach

\begin{tabular}{|c|c|c|c|c|c|c|}
\hline Values & $\begin{array}{l}\text { Average } \\
\text { limited companies } \\
(€)\end{array}$ & $\begin{array}{l}\text { Average } \\
\text { Limited companies } \\
(\% \text { TA })\end{array}$ & $\begin{array}{l}\text { Average } \\
\text { cooperatives } \\
(€)\end{array}$ & $\begin{array}{l}\text { Average } \\
\text { cooperatives } \\
(\% \text { TA })\end{array}$ & $\begin{array}{l}\text { Average } \\
\text { total sample } \\
(€) \\
\end{array}$ & $\begin{array}{l}\text { Average } \\
\text { total sample } \\
(\% \text { TA }) \\
\end{array}$ \\
\hline$\overline{V P}$ & $59,636,922$ & $100.00 \%$ & $99,794,828$ & $100.00 \%$ & $71,448,071$ & $100.00 \%$ \\
\hline M & $(32,333,479)$ & $-54.22 \%$ & $(61,274,554)$ & $-61.40 \%$ & $(40,845,560)$ & $-57.17 \%$ \\
\hline S & $(13,723,182)$ & $-23.01 \%$ & $(17,559,870)$ & $-17.60 \%$ & $(14,851,620)$ & $-20.79 \%$ \\
\hline $\mathrm{R}$ & $(964,423)$ & $-1.62 \%$ & $(1,192,740)$ & $-1.20 \%$ & $(1,031,575)$ & $-1.44 \%$ \\
\hline $\mathrm{L}$ & $(6,469,282)$ & $-10.85 \%$ & $(12,737,647)$ & $-12.76 \%$ & $(8,312,919)$ & $-11.63 \%$ \\
\hline $\mathrm{O}$ & $(497,700)$ & $-0.83 \%$ & $(736,053)$ & $-0.74 \%$ & $(567,804)$ & $-0.79 \%$ \\
\hline EBITDA & $5,648,856$ & $9.47 \%$ & $6,293,964$ & $6.31 \%$ & $5,838,593$ & $8.17 \%$ \\
\hline $\mathrm{D}$ & $(2,043,603)$ & $-3.43 \%$ & $(3,832,861)$ & $-3.85 \%$ & $(2,572,796)$ & $-3.60 \%$ \\
\hline A & $(313,107)$ & $-0.53 \%$ & $(129,165)$ & $-0.13 \%$ & $(259,006)$ & $-0.36 \%$ \\
\hline EBIT & $3,292,145$ & $5,52 \%$ & $2,321,939$ & $2.33 \%$ & $3,006,791$ & $4.21 \%$ \\
\hline SF & $(860,923)$ & $-1.44 \%$ & $(2,114,777)$ & $-2.12 \%$ & $(1,229,703)$ & $-1.72 \%$ \\
\hline $\mathrm{R}$ & $(3,451)$ & $-0.01 \%$ & $(1,373)$ & $0.00 \%$ & $(2,840)$ & $0.00 \%$ \\
\hline $\mathrm{X}$ & 29,508 & $0.05 \%$ & 378,314 & $0.38 \%$ & 132,098 & $0.18 \%$ \\
\hline$\Pi^{\mathrm{aT}}$ & $2,457,279$ & $4.12 \%$ & 584,103 & $0.59 \%$ & $1,906,345$ & $2.67 \%$ \\
\hline $\mathrm{T}$ & $(905,239)$ & $-1.52 \%$ & $(304,577)$ & $-0.31 \%$ & $(728,574)$ & $-1.02 \%$ \\
\hline$\Pi^{\mathrm{pT}^{\mathrm{T}}}$ & $1,552,040$ & $2.60 \%$ & 279,526 & $0.28 \%$ & $1,177,771$ & $1.65 \%$ \\
\hline
\end{tabular}

Source: Our processing of directly collected data 
Table 12. Financial statement of the sample firms (2011)

\begin{tabular}{lllllll}
\hline & $\begin{array}{l}\text { Average } \\
\text { Limited companies } \\
(€)\end{array}$ & $\begin{array}{l}\text { Average } \\
\text { Limited companies } \\
(\% \mathrm{TA})\end{array}$ & $\begin{array}{l}\text { Average } \\
\text { cooperatives } \\
(€)\end{array}$ & $\begin{array}{l}\text { Average } \\
\text { cooperatives } \\
(\% \mathrm{TA})\end{array}$ & $\begin{array}{l}\text { Average } \\
\text { Total sample } \\
(€)\end{array}$ & $\begin{array}{l}\text { Average } \\
\text { Total sample } \\
(\% \mathrm{TA})\end{array}$ \\
\hline$\Pi^{\mathrm{pT}}$ & $1,927,945$ & $3.23 \%$ & 385,509 & $0.39 \%$ & $1,474,287$ & $2.06 \%$ \\
$+\mathrm{D}$ & $2,138,069$ & $3.59 \%$ & $4,186,614$ & $4.20 \%$ & $2,740,582$ & $3.84 \%$ \\
$+\mathrm{A}$ & 323,277 & $0.54 \%$ & 159,915 & $0.16 \%$ & 275,229 & $0.39 \%$ \\
$+\mathrm{SF}$ & 727,012 & $1.22 \%$ & $1,748,025$ & $1.75 \%$ & $1,027,310$ & $1.44 \%$ \\
$\mathrm{CF}$ & $5,116,303$ & $8.58 \%$ & $6,480,063$ & $6.49 \%$ & $5,517,409$ & $7.72 \%$ \\
$-/+\Delta \mathrm{wc}_{\mathrm{i}}{ }^{\mathrm{T}}$ & $(1,393,614)$ & $-2.34 \%$ & $(3,061,405)$ & $-3.07 \%$ & $(1,884,141)$ & $-2.64 \%$ \\
$-/+\Delta \mathrm{WCar}^{\mathrm{a}}$ & $(269,176)$ & $-0.45 \%$ & $(1,665,970)$ & $-1.67 \%$ & $(679,998)$ & $-0.95 \%$ \\
$-/+\Delta \mathrm{WCo}^{\mathrm{a}}$ & 12,787 & $0.02 \%$ & $(631,732)$ & $-0.63 \%$ & $(176,778)$ & $-0.25 \%$ \\
$\Delta \mathrm{WC} \mathrm{aT}^{\mathrm{T}}$ & $(1,650,004)$ & $-2.77 \%$ & $(5,359,107)$ & $-5.37 \%$ & $(2,740,917)$ & $-3.84 \%$ \\
$+/-\Delta \mathrm{WC}{ }_{\mathrm{ap}}{ }^{\mathrm{s}}$ & $(66,875)$ & $-0.11 \%$ & $1,070,874$ & $1.07 \%$ & 267,757 & $0.37 \%$ \\
$+/-\Delta \mathrm{WCo}{ }^{\mathrm{s}}$ & $(562,302)$ & $-0.94 \%$ & $2,008,737$ & $2.01 \%$ & 193,886 & $0.27 \%$ \\
$\Delta \mathrm{WC} \mathrm{sT}^{\mathrm{sT}}$ & $(629,178)$ & $-1.06 \%$ & $3,079,611$ & $3.09 \%$ & 461,643 & $0.65 \%$ \\
$\Delta \mathrm{NWC}$ & $(2,279,182)$ & $-3.82 \%$ & $(2,279,496)$ & $-2.28 \%$ & $(2,279,274)$ & $-3.19 \%$ \\
OCF & $2,837,121$ & $4.76 \%$ & $4,200,567$ & $4.21 \%$ & $3,238,135$ & $4.53 \%$ \\
$-/+\Delta \mathrm{FA}$ & $(2,400,033)$ & $-4.02 \%$ & $(8,886,563)$ & $-8.88 \%$ & $(4,301,954)$ & $-6.02 \%$ \\
$\mathrm{UFCF}$ & 437,088 & $0.73 \%$ & $(4,665,996)$ & $-4.68 \%$ & $(1,063,819)$ & $-1.49 \%$ \\
$-\mathrm{SF}$ & $(727,012)$ & $-1.22 \%$ & $(1,748,025)$ & $-1.75 \%$ & $(1,027,301)$ & $-1.44 \%$ \\
FCFE & $(289,924)$ & $-0.49 \%$ & $(6,414,021)$ & $-6.43 \%$ & $(2,091,129)$ & $-2.93 \%$ \\
\hline
\end{tabular}

Source: Our processing of directly collected data

Only in a steady-state situation (no change in the extension granted and received by customers and suppliers, no variation in the average number of days of inventory, no change in turnover) do we have the equality, even with lag time, between income and financial margins (Iotti and Bonazzi, 2014). On this topic, the analysis shows that margins calculated with an economic approach, which are EBITDA, EBIT and PROFIT, often differ significantly from the margins calculated with a financial approach $(\mathrm{CF}, \mathrm{OCF}, \mathrm{UFCF}$ and FCFE). This shows that income margins do not adequately approximate the creation of financial liquidity generated by the management of the companies in the sector. This is especially true for UFCF and FCFE. In particular, the values of FCFE are very low because of the high level of debt that companies in the sector reach for financial investments in fixed assets. In addition, the sector's firms have often a high level of PROFIT, but these values cannot be distributed to equity holders because of lack of financial liquidity; in fact, firms in the sample often have positive PROFIT (50 cases), while there are only a limited number of cases of positive FCFE (37), which means that, in 13 cases, firms are not able to distribute PROFITs to shareholders because of lack of available cash. The analysis shows a low correlation between income margins (EBITDA, EBIT and PROFIT) and financial margins (OCF, UFCF and FCFE). This result confirms the descriptive statistics because it shows that positive income margins do not lead to equally positive financial results and even between these two approaches, there is no correlation of results. This finding is significant because the firms in the sector often base assessment on income margins and rarely use cash flow statements for the analysis. The analysis also shows that the processing firms in the tomato sector are characterized by income margins higher than financial margins and this difference is statistically significant. This result suggests that the income margins routinely used to assess the sustainability of the business cycle (EBITDA and EBIT) are not able to express this ability, which is a strictly financial capacity. The income margins cannot be used as variables that approximate the generation of liquidity (OCF and UFCF). The ICRs suggested and applied in work differ significantly if compared with traditionally applied ICRs, which have an income approach; the suggested ratios could then be usefully applied by managers and financial institutions, such as banks, for the assessment of affordability and sustainability of the business cycle. In fact, the research shows that, for the firms sampled, ICRs with a financial approach are lower than ICRs with an economic approach and then it is necessary to consider this fact in the case of evaluating companies' ability to repay debts. The sustainability assessments carried out with an economic approach overestimate firms' ability to serve debt, thus providing distorted information to a firm's 
manager. Financial ratios considered in the article could be applied even by financial intermediaries to assess the affordability and sustainability of the firm's cycle, particularly in the tomato sector, where firms are often capital-intensive because of the high level of required investment in both fixed assets and working capital. The analysis thus shows that the proposed regression models have an explanatory capacity of FCFE; in particular, the financial model, as expressed in Equation (10), has a higher fit: The $\mathrm{F}$ statistic for the considered model has a high significance $(F=0.000)$ and the adjusted $R^{2}$ is 0.955 . The model expresses an important result for the tomato sector: The flow of FCFE is affected more by financial variables, while the intermediate profit margins have a lower explanatory power.

\section{CONCLUSION}

The analysis of the companies in the tomato processing industry sector, located particularly in the Emilia-Romagna, Lombardia and Piemonte regions, shows that these firms have characteristics of production and investment that affect capital structure, even influencing income and financial structures. These companies need large amounts of capital, in terms of equity capital and/or debt, to support investments in fixed assets (buildings, plants and equipment for tomato processing) and working capital (inventories, including finished goods and accounts receivable). In view of the high absorption of capital due to investment and the working capital cycle and due to the high level of debt, it is necessary to assess the sustainability of the business cycle. For this purpose, in the article, intermediate profit margins (EBITDA, EBIT and PROFIT) of the firms are calculated; we compare economic and financial margins (CF, OCF, UFCF and FCFE) to verify if these different margins are related and whether there are statistically significant differences between economic and financial margins. The analysis shows that there are significant correlations between income margins and financial margins but that these correlations (Pearson correlation for a parametric and Spearman's $\rho$ for a nonparametric approach) are limited to intermediate margins (EBITDA and EBIT) and OCF. The article thus shows that there is no correlation between economic margins and UFCF and between PROFIT and FCFE. For firms in the sector, economic margins cannot be used as proxies to quantify cash flow generation and there is often no possibility of distributing dividends, even in the presence of positive profit. The result of the analysis is that the mean economic values (median for a nonparametric approach) are higher than the financial values. The analysis thus shows that there is a risk of overestimating financial sustainability: The firms of the tomato processing sector, in fact, have financial difficulties even in the case of positive margins, as shown by the values of financial margins (UFCF and FCFE in particular). The firms in the sector, then, need control systems, including financial statements, for the purposes of internal analysis and also for relations with the credit system. In fact, the data analysis expresses that fixed investments and the expansion of working cycle capital (inventories and accounts receivable) have a negative effect on the absorption of liquidity. This situation, which in the past has caused many situations of bankruptcy, is reflected by the high level of debt in the sector with modest capitalization in terms of equity capital. Debts are, in fact, the primary source of capital, so it is important to analyze the relationship between sector firms and banks. On this topic, policy makers could consider these characteristics of the annual accounts of companies in the tomato sector for aid policies (e.g., through subsidiary guarantees issued by credit unions to improve the sustainability of the business cycle). The companies in the sector could, in any case, recover margins of efficiency in the generation of liquidity, given the situation of rising prices of raw materials. The analyzed data show that there are difficulties in the sustainability of the financial management cycle for the firms sampled, particularly in the payment of the cost of debt. These situations are expressed clearly by applying the suggested ratios calculated with a financial approach. For firms in the sector, we have applied the assessment of the sustainability of debt servicing (ICRs) that highlights important results. In fact, sustainability evaluation is carried out with the traditional ICRs and calculated with an income approach $\left(\mathrm{ICR}_{1}\right.$ and $\left.\mathrm{ICR}_{2}\right)$; the analysis shows that economic ICRs have values higher than financial ICRs $\left(\mathrm{ICR}_{3}\right.$ and $\left.\mathrm{ICR}_{4}\right)$. These financial ratios could then be applied with greater significance because they are able to express more correctly a firm's capacity to pay debt services. The use of ratios for sustainability evaluation may have utility for a firm's owner to properly assess the sustainability of the management cycle and even for credit institutions that could assess with greater accuracy the creditworthiness of companies. At the same time, the method could be applied by policy makers, operating with direct (loans) or indirect (mutual guarantees) aid policies in favor of the tomato sector; in fact, an increased capacity to evaluate the sustainability of the cycles of firms that have received public funds is useful to reduce the risk of inefficient uses of collective resources. The applied regression analysis shows that FCFE creation is analyzed properly by applying a multiple regression model. The explanatory variables of 
FCFE generation are capital turnover (TURNOVER), Return on Sales (ROS), cycle of working capital (I_days, AP_days and AR_days) and in particular, some intermediate financial margins. The signs of the coefficients of the explanatory variables are consistent with the economic theory, expressing the quality of the regression model's adaptability. Even on this topic, the research could constitute a prerequisite for other empirical works aiming to apply the methodology to a different sector's firms, especially if characterized by a high level of investment in fixed assets.

\section{ACKNOWLEDGEMENT}

This study is a result of the full collaboration of all the authors. However M. Iotti wrote, Materials and Methods, Results, Regression Analysis while G. Bonazzi wrote Introduction, Discussion and Conclusion.

\section{RERERENCES}

Alrafadi, K.M.S. and M. Md-Yusuf, 2011. Comparison between financial ratios analysis and balanced scorecard. Am. J. Econ. Bus. Admin., 3: 618-622. DOI: 10.3844/ajebasp.2011.618.622

Almeida, H., M. Campello and M. Weisbach, 2004. The cash flow sensitivity of cash. J. Finance, 59: 17771804. DOI: 10.1111/j.1540-6261.2004.00679.x

Altman, E.I., 1968. Financial ratios, discriminant analysis and the prediction of corporate bankruptcy. J. Finance, 23: 589-609. DOI: 10.1111/j.15406261.1968.tb00843.x

Bahiraie, A., N.A. Bt Ibrahim and A.K.M. Azhar, 2009. On the Predictability of Risk Box Approach by Genetic Programming Method for Bankruptcy Prediction. Am. J. Applied Sci., 6: 1748-1757. DOI: 10.3844/ajassp.2009.1748.1757

Barnes, P., 1987. The analysis and use of financial ratios: A review article. J. Bus. Finance Account., 14: 449461. DOI: $10.1111 / \mathrm{j} .1468-5957.1987 . t b 00106 . x$

Beaver, W.H., 1966. Financial ratios as predictors of failure. Empirical research in accounting: Selected studies. Supplement J. Account Res.

Bonazzi, G., M. Iotti and F. Paduano, 2012. Valutazioni di convenienza e di sostenibilità per le imprese del comparto del Prosciutto di Parma Dop: Un'analisi attraverso l'applicazione di incidi economici e finanziari. Rivista di Economia Agraria, 2: 6-98.

Carroll, C. and J.M. Griffith, 2001. Free cash flow, leverage and investment opportunities. Q. J. Bus. Econ. 40: 41-41.
Chittenden, F., P. Poutziouris and N. Michaelas, 1998. Financial Management and Working $\mathrm{Ca}$ pital Practices in UK SMEs. 1st Edn., Manchester. Manchester Business School, ISBN-10: 0903808773, pp: 27.

De Miguel, A. and J. Pindado, 2001. Determinants of capital structure: New evidence from spanish panel data. J. Corporate Finance, 7: 77-99. DOI: 10.1016/S0929-1199(00)00020-1

Dechow, P.M., S.P. Kothari and R.L. Watts, 1998. The relation between earning and cash flows. J. Account. Econo., 25: 133-168. DOI: 10.1016/S01654101(98)00020-2

Demerjian, P., 2011. Accounting standards and debt covenants: Has the "balance sheet approach" led to a decline in the use of balance sheet covenants? J. Account. Econo., 52: 178-202. DOI: 10.1016/j.jacceco.2011.08.004

Dichev, I. and D. Skinner, 2002. Large-sample evidence on the debt covenant hypothesis. J. Account. Res., 40: 1091-1123. DOI: 10.1111/1475-679X.00083

Dothan, M., 2006. Costs of financial distress and interest coverage ratios. J. Financ. Res., 29: 147-162. DOI: 10.1111/j.1475-6803.2006.00171.x

Ezzamel, M., J. Brodie and C. Mar-Molinero, 1987. Financial patterns of Uk manufacturing companies. J. Bus. Finance Account., 14: 519-36. DOI: 10.1111/j.1468-5957.1987.tb00110.x

Fazzari, S. and B. Petersen, 1993. Working capital and fixed investment: New evidence on financing constraints. Rand J. Econo., 24: 328-342.

Finger, C.A., 1994. The ability of earnings to predict future earnings and cash flows. J. Account. Res.

Giacomino, D.E. and D.E. Mielke, 1988. Using the statements of cash flows to analyze corporate performance. Manag. Account.

Gitman, L.J., 1994. Principles of Managerial Finance. 1st Edn., Harper Collins, London.

Goldstein, R., N. Ju and H. leland, 2001. An EBIT-based model of dynamic capital structure. J. Bus., 74: 483512.

Gombola, M.J. and E.J. Ketz, 1983. Note on cash flow and classification patterns of financial ratios. Account. Rev. LVIII1.

Grablowsky, B.J., 1984. Financial management of inventory. J. Small Bus. Manag.

Gray, S., A. Mirkovic and V. Ragunathan, 2006. The determinants of credit ratings: Australian evidence. Aus. J. Manag., 31: 333-354. DOI: 10.1177/031289620603100208 
Healy, P.M., 1985. The effect of bonus schemes on accounting decisions. J. Account. Econo., 7: 85-107. DOI: $10.1016 / 0165-4101(85) 90029-1$

Henry, D., 1996. Cash Flow and Performance Measurement: Managing for Value. 1st Edn., Financial Executives Research Foundation, New York, Morristown.

Hill, M.D., W.G. Kelly and M.J. Highfield, 2010. Net operating working capital behavior: A first look. Financ. Manage., 39: 783-805. DOI: 10.1111/j.1755-053X.2010.01092.x

Howorth, C. and P. Westhead, 2003. The focus of working capital management in UK small firms. Manag. Account. Res., 14: 94-111. DOI: 10.1016/S1044-5005(03)00022-2

Iotti, M. and G. Bonazzi, 2013. Assessment of return on investment and sustainability of the business cycle in the meat processing sector in Italy. Afr. J. Agric. Res., 8: 5051-5063. DOI: 10.5897/AJAR12.1908

Iotti, M. and G. Bonazzi, 2014. Financial and income approach analysis in Micro (MEs) and Small/Medium Sized Enterprises (SMEs): A comparative approach in fruit and vegetables processing industry in Italy. Afri. J. Agric. Res., 9: 240-54. DOI: $10.5897 / A J A R 12.1859$

Kim, C., D. Mauer and A. Sherman, 1998. The determinants of corporate liquidity: Theory and evidence. J. Financ. Quantitative Anal., 33: 335-359. DOI: $10.2307 / 2331099$

Leland, H.E., 1994. Corporate debt value, bond covenants and optimal capital structure. J. Finance, 49: $\quad 1213-1252$. DOI: $10.1111 / \mathrm{j} .1540-$ 6261.1994.tb02452.x

Leland, H., 1998. Agency costs, risk management and capital structure. J. Finance, 53: 1213-1243. DOI: 10.1111/0022-1082.00051

Lorek, K.S. and G. Willinger, 1996. A multivariate times series prediction model for cash flow data. Account. Rev.

Love, I., L.A. Preve and V. Sarria-Allende, 2007. Trade credit and bank credit: Evidence from recent financial crises. J. Financ. Econo., 83: 453-469. DOI: 10.1016/j.jfineco.2005.11.002
Massari, M., 2000. Finanza aziendale: Principi di analisi finanziaria. Egea, Milano.

Nasir, N.M. and S.N. Abdullah, 2004. Information provided by accrual and cash flow measures in determining firms' $\square$ performance: Malaysian evidence. Am. J. Applied Sci., 1: 64-70. DOI: 10.3844/ajassp.2004.64.70

Onida, P., 1987. Economia d'azienda. UTET, Torino.

Padachi, K., 2006. Trends in working capital management and its impact on firms' performance: An analysis of mauritian small manufacturing firms. Int. Rev. Bus. Res., 2: 45-58.

Rayburn, J., 1986. The association of operating cash flow and accruals with security returns. J. Account. Res., 24: 112-133.

Sartoris, W. and N. Hill, 1983. A generalized cash flow approach to short-term financial decisions. J. Finance, 38: 349-360. DOI: 10.1111/j.15406261.1983.tb02240.x

Shin, H.H. and L. Soenen, 1998. Efficiency of working capital and corporate profitability. Financ. Practice Educ.

Sloan, R.G., 1996. Do stock prices fully reflect information in accruals and cash flows about future earning. Account. Rev., 71: 289-315.

Taylor, D., 2011. Optimizing Working Capital. 1st Edn., Business Credit, VI.

Weinraub, H.J. and S. Visscher, 1998. Industry practice relating to aggressive conservative working capital policies. Pennsylvania State University.

Whittington, G., 1980. Some basic properties of accounting ratios. J. Bus. Finance Account., 7: 219232. DOI: $10.1111 / j .1468-5957.1980 . t b 00738 . x$

Wilson, G.P., 1987. The incremental information content of the accrual and funds components of earnings after controlling for earnings. Am. Account. Assoc., 62: 293-322.

Zappa, G., 1950. Il reddito d'impresa. Giuffrè, Milano. 